\title{
Language Games in Turkish and Russian Television Commercials $^{1}$
}

\author{
Nükhet ELTUT KALENDER \\ Yuzuncu Yil University, Van, Turkey
}

\begin{abstract}
Advertisement and presentation of a product is the most important stage in the process of marketing. Product advertisement mostly benefits from the audiovisual commercials and advertisements on mass media (television, radio, newspaper, magazine, poster, brochure, Internet etc.). Today, TV, radio and Internet are considered to have great importance among the most widely used means of mass media. Initial advertisement for each product plays a significant role in getting a bigger market share for that product. Thus, manufacturing companies need brands, taglines, catchphrases and jingles for their commercials broadcasted on mass media. Astonishing words or expressions which catch the consumers' attention play a highly significant role in commercials. Slogans which are created sometimes using melodious or rhythmical expressions, and imperatives, or sometimes slang and daily language support convincing power of the commercials. The mentioned slogans are indeed examples of creativeness. This study primarily includes the commercials, ways to produce slogans and their characteristics, together with identifying the slogans in the commercials broadcasted in Turkey and Russia, created by using language games, which include brand names. Then, aforementioned slogans will be reviewed with regards to artistic stylistics, a sub branch of functional stylistics. Finally, similar and different aspects of the language games in Turkish and Russian commercials will be compared based on the findings obtained from the analyses.
\end{abstract}

Keywords: television commercials, brands in TV commercials, commercial slogans on TV, language games, artistic stylistics

\section{Introduction}

Recent technological developments and excessive demands entail manufacturing new goods. The fierce competition for selling those manufactured goods in bigger markets and eagerness to sell more have pushed the organizations and enterprises in seeking new markets. Efficient advertising is the most important way to sell a product (Çınar \& Karahan, 2009, p. 892).

Bilim ve Sanat Terimleri Sözlüğ̈̈/Iktisat Terimleri Sözlüğü (Dictionary of Financial Terms), published by The Turkish Language Association in 2004, defines the term "advertisement" as "An activity performed by a company intending to increase the sales and the demand for its products by influencing the consumers' tastes and preferences". However, in Güncel Türkçe Sözlük (Contemporary Turkish Dictionary) it is explained as "Any method to introduce something and gain consumer acceptance in order to maintain demand and

\footnotetext{
1 This article is extended and enhanced version of paper presented at 3rd Global Conference on Linguistics and Language Teaching in 2015 year.

Nükhet ELTUT KALENDER, Department of Russian Language and Literature, Faculty of Letters, Yuzuncu Yil University.
} 
circulation". From the stand point of manufacturers, who compete against the rivals in the search of new markets advertisements enable introducing the products to the target market, meanwhile allowing the consumers to make a preference among the products, that fit their needs best and are similar in terms of specifications, quality and price. Among the means of mass media, especially television is the most efficient one with respect to its audio-visual capabilities. Therefore, advertising agencies produce short films for the products to be introduced and promoted. The intended concept in these introductory films is presented to the target population as short and brief as possible but in company with purposely produced music or through some slogans.

Y1lmaz (2004) suggests that advertising text is "the final form of the advertising message, that will be introduced to the target population by using verbal, written and auditory materials in any type of media" and he also thinks that it is a "set of communications" that fills the communication gap, resulting from the market economy, between the manufacturer and the consumer.

The product gains memorability in the minds of consumers depending on its special symbols. Slogan is one of the most important symbols. The slogan of an advertisement, summarizing the concept of advertisement, can be created from a memorable title or an interesting sentence in the advertisement. It provides memorability for the concept of the advertisement (Mengü, 2006, p. 114).

Expressions and sentences, which are used in advertisements, are called as slogans in general. The origin of slogan is English; it can be translated into Turkish as özdeyiş (apothegm) or vecize (maxim) (Ateşoğlu, 2003, p. 260). The following statement by Ateşoğlu underlines the essential role of slogans in building the brand image: "The use of slogans is a factor that contributes to the memorability and convincing power of the symbol of the brand and the product", similar to the above quotation from Mengü (2006, p. 114), which is about the active role of slogans in advertisements (2003, p. 262).

\section{Method}

The commercials, which have been broadcasted in Turkish and Russian TV channels in the last two decades, are compiled in order to conduct the research. Whether the brand of the product is included in the commercial, or not has been determined, after reviewing these compiled slogans. The study focuses on the question of which stylistics language game is used for the brand in the commercial.

\section{Stylistics Issues in Advertisement Texts}

One of the main issues that should be considered in the process of preparing an advertisement text is having an appropriate style in the advertisement text for the target population. The expressions that are used in TV commercials can be reviewed under the sub-group of functional stylistics, a linguistic branch of stylistics. However, the advertisement text is a multidisciplinary research topic. Especially, in terms of stylistics, literary scholars and linguists have not been able to clarify which category the advertisement texts fall into (Kozhina, Duskaeva, \& Salimovsky, 2014). Some researchers include the advertisements in artistic stylistics; some others consider them under the category of pragmatic stylistics, while the others suggest that they should be considered under the category of publicistic stylistics. Below are the primary opinions about this issue:

Aytaç (2000, p. 83) states that Elise Riesel, the representative of functional stylistics researches, suggests that "Stylistics is the discipline of using the language appropriately for the function in all the scopes of verbal activity". She also adds that Riesel makes reference to five type of functional stylistics, in which a language 
undertakes specific communication functions: (1) official style, (2) scientific style, (3) publicistic (Media and press) style, (4) colloquial style and (5) literary style. Riesel's classification is based on the functional criteria of monolog-dialog, written-verbal, literary language, colloquial language.

Özünlü suggests that in a written work an author may use the language with one or more of personal or subjective, informative or objective, evocative, persuasive, logical or artistic aims. Besides that, in the light of these aims and also by benefiting from its specific studies, stylistics reviews the written works in terms of the use of language (Özünlü, 2001, pp. 20-21).

Aytaç remarks that stylistics deals with all verbal products in general, as well as various pattern forms, such as advertisement, propaganda, slogan, newspaper advertisement, business letter etc. which are expected to have practical benefits and she says, that this scope is called as pragmatic stylistics (2000, pp. 93-94).

According to Polonsky the language of modern mass media glamorizes the semantic structure of the language rather than making the pragmatic potential of the words stronger and ensuring the development and quantitative growth $(2009$, p. 64).

Okan, in a quotation from Cook (1992), states that when the advertisements are reviewed, it is seen that the researches about the relation between advertisement and language primarily focus on stylistic linguistics, rather than language production and the factors affecting this process, however, the text reviews in recent years make it clear that these forms and semantic analysis are left behind and function of the text came to the forefront (Okan, 1998, p. 193).

Çınar and Karahan, in a quotation from Özünlü, suggest that the language used in advertisements and poetry have similar characteristics: some methods are used to facilitate voicing the poems and linguistic properties of the advertisement language are manipulated in order to draw the buyers' attention easily (2009, p. 893). Ince asserts that various attention catching and persuasive methods are used in advertisement texts to achieve the goal of selling the product, furthermore,

From the linguistic point of view, these methods are implemented through creative literary techniques, such as poetic language, linguistic deviations, repetitions in sound, word or sentence levels, chorus in which music and language are used together, use of theatrical items with the language, or language arts, such as metaphors, imitation and personification. (İnce, 1993, p. 233)

Language and visual instruments have a communicative value, as long as they complete each other. This is especially very important in TV commercials, which primarily benefit from language and image. Images do not only introduce or present a product to the consumer, they also have a unique ability to bring the viewers in front of the screen. On the other hand, telling the distinctive properties and benefits of the product, giving messages that intend to increase the sales force and also maintaining memorability for these are possible only through language (İnce, 1993, p. 238).

Characteristics, such as being short, not previously used or standing out among the other brand slogans, intriguing, arousing curiosity, drawing attention to the brand's distinctive properties, emphasizing the benefits for the consumers, interesting, striking even funny indicate that the slogan has the properties of a good advertisement slogan. Advertisement texts may consist of monologs or dialogs. Usually, the language that is used in advertisement texts may be a mixture of colloquial language and artistic language. Artistic language refers to using a word or a sentence in a more aesthetic way, which the dictionaries do not cover. Thus, within the frame of functional stylistics suggested by Aytaç the advertisement texts can't be included in publicistic or 
colloquial stylistics. Although, means of mass media are a part of media and press, the advertisement texts, which are used in TV commercials and called as slogans, can be reviewed under literary stylistics, according to the categorization made by Riesel. Rozental' prefers literary-art stylistics title for this category. Therefore, in terms of aesthetic expression, literary texts, as well as any other text can be reviewed in this group (Lytkina, Selezneva, \& Skorokhodova, 2013).

\section{Language Games in Advertisement Slogans}

In advertisement texts, the artistic games first influence the perception and the memory. Every day, people hear or read lots of advertisements, thus advertisement texts need an instrument in order to be remembered. Maintaining conformity between the slogan and the reminder is one of the most efficient methods to facilitate perception of the text and text components by the consumers. In other words, having two or more coherent words in the text significantly increases memorability. Important information, such as brand name, basic consumer benefit or at least an indication of product category must be the aim of the conformity. The slogans "Ваша киска купила бы Вискас" (Vasha kiska kupila by Whiskas) for Whiskas food for cats; "Ровента: радость в вашем доме" (Rowenta: radost' v vashem dome) in the advertisement text of Rowenta home appliances; "Наш дом-Домино" (Nash dom-Domino) for Domino trade company; "Чистота-чисто Тайд" (Chistota-chisto Tide) in Тайд/Tide detergent commercial are the examples for using conformity as a reminder item for the new name of the brand (Serdobinceva, 2010, p. 34).

Advertisement language is one of the areas, in which people are most creative. Using some words, sentences or slogans that are used in advertisements in daily life for humor, is another semantic effect of advertisements (İnce, 1993, p. 242).

Word game is a very common method in Russian commercials. Calling this method as "semantic game" would be more appropriate, because meaning is the primary object and part of the meaning differentiation. Such word games also involve punning and "matryoshka" words ${ }^{2}$. Punning has been known for many years as a stylistic figure and it can be built on homonyms and polysemy. In the use of punning (1) the word game should contain a word, that emphasizes the importance of the advertisement, (2) the meaning of the derivative punning, derived from a word game, should be coherent with the subject of the advertisement. This condition is related with the use of homonymous words which do not contain general meaning components, (3) the semantic game should be intelligible for everybody. Like all other methods, the word games that are used in creating advertisements, also serve for the commercial interests of the advertiser (Serdobinceva, 2010, p. 39).

Emphasizing a certain part of the word in advertisement text with graphics and creating a completely new word that has a special meaning is very common. The word "КачестВО", which accompanies a thumb up figure in an assessment gesture, is a good example for this. The success of the advertisement is directly linked to its linguistic expression. All the level units in language are effective in the process of creating attention grabbing and memorable texts (Serdobinceva, 2010, p. 40).

Especially, presenting the slogan with the visual components makes the target population envision the advertised product. Advertisement text writers emphasize that different stylistics games and expressive instruments should support and accompany the slogans in order to have a positive envision in minds. Advertisement effectiveness can be achieved through the use of stylistically glamorized linguistic components,

2 The fact that a whole word constitutes a part of another word (word in word) is compared and called as "Matryoshka" words. i.e., КачестВО, Новая ФАНТАстическая бутылка еtс. 
such as phonetic, graphical, lexical, morphological and syntactic components.

\section{Language Games in Turkish Television Commercials}

Anadolu Hayat Sigorta (Anatolia Life Insurance) - Hayat uzmanı (Life expert): The company name already includes the company's operational scope, so that using the company name draws the attention to the word Hayat (Life), which is the business segment of the company. In addition to this, it establishes in the minds the perception that the company has enough expertise which also instills confidence. The polysemous structure of the word serves the purpose here.

Aroma - Aroma'dan başkasını arama (Don't look for anything, except Aroma): The brand name (Aroma), which is a fruit juice advertising slogan, gives the consumers a message that it is the best among the rivals in the market, by using a graphical language game method and changing the " $o$ " letter in the second syllable of the brand name, then transforming it into an imperative in Turkish "arama", which means "do not look for". In addition to this, the melodic slogan increases the memorability of the commercial.

Ayakkabı Dünyası (World of Shoes) - Ayakkabı Dünyası'nda dünyanın ayakkabısı var (All the shoes of the world in the World of Shoes): The commercial uses a slogan, which includes the brand name. The order of the shoes and world in the slogan is changed in order to catch attention and emphasize the very wide range of products. A language game based on syntactic and word repetition is used.

Aytaç@-@ kalite lezzet (@ quality tastes) / Hayatınıza lezzet katın (Flavour your life): Çınar and Karahan (2009) state that "a kalite" (a quality) means "premium quality”. The symbol “@” resembles the letter " $a$ " which is the initial letter of the brand name and the brand logo. Furthermore, when "@" is pronounced it means "meat" in Turkish, the operational scope of the company. This commercial is in the category of advertisement slogans using graphical language games.

Benim o (It's mine) - Benim o diyorsam, Benim o (If I say it's mine, it's mine): We see that the biscuits brand uses a language game created through word repetition in its advertisement slogan. The commercial emphasizes the sense of belonging and also the biscuit has such a great taste that it is impossible to share it at any cost.

Bizim Yağ (Our Oil) - Var mı Bizim gibi lezzetlisi? (Is there such a delicious oil like Our Oil?): The word "bizim" has two meanings in the commercial of the brand, which is a solid and liquid vegetable oil producing company. Firstly, it refers to the products produced by the brand. Secondly, it is used instead of "our products", which means that it is unique in terms of taste among the other products in the market. It is seen that the language game in this slogan benefits from a metaphorical method by using the word "bizim" (us) and the preposition "gibi" (like) together.

Dizayn Grup - Türkiye alt yapısında Dizayn istiyor (Dizayn Group - Turkey needs Design for its infrastructure): The brand name is partially used in the commercial, which promotes infrastructure products. The capitalized word "dizayn" (design) in the advertisement slogan makes a reference to the brand name, besides there is a lexical language game since the word "design", that is originally English, means "planning, layout" in Turkish.

Eti Form - Hayatı hafife al, Form ye, Formda kal (Eti Form - Make light of life, eat Form, keep in Form): In the commercial of the company, which produces light snacks, it is seen, that the brand name is used in two different sentences with two different meanings. The word "hafif" (light) in the slogan emphasizes, that it is a diet product and the capitalized word "form" draws the attention to the brand name. However, the second 
sentence, a melodic expression, intends to convince the consumer that the product helps "keeping healthy and fit". The language game in the commercial, benefits from the polysemous word.

Fiat Stilo - Yeni Stil O, yaşamadan bilemezsiniz (Fiat Stilo - It is the new Style, you will not feel it if you do not live it): In the commercial of Fiat, promoting the new style vehicles, the brand name "Stilo" is divided into two as "Stil" (style) and "O" (it) by benefiting from graphical language game method. The capitalized word "Stil" (Style) repeats the brand name, furthermore "It is the New Style" refers to the latest fashion and the latest style, also expressing the popularity of the vehicle.

Hayat Su (Life Water) - Su Hayat'tır, Hayat güzel... (Water is Life, Life is beautiful)...: In the commercial of the natural mineral water brand, it is seen, that the language game, by changing the places of hayat (life) and su (water), benefits from a syntactic change, word repetition and polysemy. In the first part of the slogan, the words hayat (life) and su (water) make a reference to the fact that "life is impossible without water" and "vital importance of water", in addition to this there is also a proportional link between water and life. The expression of water = life in the second part of sentence means life is beautiful and the beauty of life is directly linked to water. The capitalized initial letter again points at the brand. Furthermore, the word "hayat" (life) in the statement of "Hayat güzel" (Life is beautiful) does not only represent the brand, but it also (Life is beautiful) communicates the consumers that water $=$ life $=$ beautiful .

Denizbank - Hayat Deniz'de güzel (Denizbank - Life is good at Sea)...: The word "Deniz" (Sea) is capitalized in the slogan to emphasize, that it is a part of the brand name. The apostrophe in the slogan does not only separate the -de case suffix from Deniz as in Deniz'de, but it also emphasizes, that the word Deniz (Sea) is a private name. Using a sea scene as a background in the commercial, shows, that the language game in the advertisement benefits from polysemy, since the word "deniz" is the name of the bank and means sea.

Halley - Herkese bi Halley oluyor (Halley - Something odd is going on around everybody): When the word "haller", which means "to have odd behaviors", is pronounced in the advertisement slogan of Ülker's biscuit sandwich, filled with marshmallow and covered with chocolate, the last consonant $-r$ is deliberately articulated as $-y$, so that the word becomes the same as the product name "halley". These odd behaviors are attributed to Halley and the message communicates the consumers, that the wonderful taste of the product changes the personal mood. Pronouncing the brand name melodically in the slogan, by changing $-r$ into $-y$, enables the consumers to remember the slogan easily. The commercial, benefits from graphical language game.

İstikbal Mobilya - İstikbal'de yaşanacak çok şey var (İstikbal Furniture - There are many things to live with İstikbal): Capitalizing the brand name in the advertisement slogan and separating the case suffix -de by using an apostrophe emphasize, that the brand name "istikbal" is used as a private name instead of Istikbal stores. Furthermore, the word "istikbal" in advertisement slogan means "future". This commercial is an example for the language games, which benefit from polysemy.

Kilim Mobilya - Bi' Kilim yeter sevgilim (Kilim Furniture - Darling, a Rug is enough): Capitalization of Kilim refers to the brand name of the furniture manufacturing company, while the word "Kilim" in the commercial communicates the message, that for a warm and happy home a "Rug" is enough. The slogan has the message, that for a happy and modest marriage the products of Kilim Furniture are enough, no other product is needed. The language game in the commercial, benefits from the polysemous word.

Nazar Şekersiz Sakız (Nazar Sugar free chewing gum) - Nazar'a nazar kaç yazar? (Evil eye on Nazar, eh? (colloquial style)): The word "nazar" is used twice in the advertisement slogan for the sugar free chewing gum. Capitalization of nazar and separation of the preposition - $a$ (to) emphasize, using the brand name 
as a private name. However, the word nazar, the second one in the sentence, also means "evil eye, jealous or hostile look". The language game in this commercial takes advantage of the polysemous word.

Pril - Limonlu Prille pirll pırıl (Pril - Perfectly bright with Pril Lemon): The detergent brand name is used in the slogan and the following word repetition "pirll purll" (perfectly bright) emphasizes the detergent's capability of making the dishes shine. The letters " $p, r$ and $l$ ", which are common in both words (Pril and prril), only match in written form and pronunciation, but the words do not have a semantic affinity. This commercial benefits from the phonetic language game.

Renault Clio Symbol - Memnuniyetin Symbol'ü (Renault Clio Symbol - The Symbol of satisfaction): Capitalization of the word "Symbol" in the advertisement slogan of the model manufactured by Renault and separation of " $\ddot{u}$ " (definite article in Turkish) by an apostrophe emphasize the use of brand name as a private name. Additionally, it is seen, that the letter -e in the word "sembol" (symbol in Turkish) is replaced with $-y$ as similar to the brand name "Symbol". The slogan communicates the message that the new model introduced symbolizes the satisfaction of the consumers. Preferring symbol (English) instead of sembol (Turkish) in the advertisement slogan shows that a graphical language game is used.

SekSüt - İçSEK, büyüSEK (Drink SEK, Grow SEK (it would be nice, if we drank milk and grew)): It is seen, that a suffix, which is the synonym for "if" in Turkish, is added at the end of the words "iç" (drink) and "büÿ̈" (grow). The suffix that is added at the end of these verbs is the same as the brand name "SEK". The slogan communicates the message that drinking milk speeds up growing. The use of brand name in this advertisement slogan is created through graphical language game.

Yağmur Mobilya - Yağmur'a tutulacaksınız (Yağmur Furniture - You will get caught in the Rain): The word "Yağmur" refers to a weather event. Using an apostrophe to separate the $-a$ (to in Turkish) from the word "Yağmur" emphasizes the brand name and it is a private name. Additionally, the expression "Yağmur'a tutulacaksinı" (You will get caught in the rain) gives the message, that their products have the right qualities to appeal consumers. The language game in the commercial benefits from the polysemous word.

\section{Language Games in Russian Television Commercials}

Атлант - талантливая техника (Atlant - Talented technique): This commercial benefits from the phonetic language game, as the consonants " $t, l, n, t$ ", that constitute both the brand name "Atlant" and the word "Talented", which is the English synonym for feminine gender Russian word "талантливая", match.

«Балтика». Там, где Россия ("Baltika". There, where Russia is): The manufacturing company associates the product name with the fact that Russia has a coastline on the Baltic Sea. The sentence "TaM, гde Poсcuя", which means "Where Russia is", emphasizes the homeland of the manufacturing company. The brand and the manufacturing company are emphasized in the commercial through a lexical language game.

В дрова с водкой Drova (Drova vodka to the firewood!): The brand name is capitalized and written with Latin letters in order to emphasize the brand name, which is known as organic vodka for being filtered through oak, walnut and silver birch coal. The Russian word "дрова", which means firewood, makes a reference to the content and production method of the alcoholic drink. The language game in this commercial benefits from the polysemous words.

Вам негде жить?Есть идея - есть ИКЕА (You have nowhere to live? There is an idea - there is IKEA): In the commercial, a young couple rents a house and starts thinking what to do next, then an idea occurs to the young man and they go to IKEA. In this commercial the connection is based on the common $i, e$, 
$a$ (ja) vowels in the words "uдеs", which means idea, and "ИКEA" (IKEA). It is seen, that a phonetic language game is used in this commercial.

Ваша киска купила бы Whiskas (Your pussycat/kitty would buy Whiskas): Writing the name of the cat food brand in English as original and capitalized grabs the attention. There is a phonetic language game that is based on using the common $i, s, k$ consonants in the words Whiskas and киска, which means pussycat/kitty in Russian.

Volvo - Безопасное удоVolvствие (Volvo - Safe pleasure): In the commercial of Volvo, the Russian word "удоволвствие", which means pleasure, is written with Cyrillic and Latin alphabets. Volvo is written as Volv with Latin letters and the second "- $o$ " at the end of the word is omitted, in order to draw the attention to the word "-вольв-" [-vol'v-], which is in the middle of the word "Удовольвствие". The graphical language game in the commercial is based on the word "удовольствие", which exists in Russian but mistyped.

Вольво (S40) - Жемчужная эVOLVOлюции (Volvo (S40) - Pearl of eVOLVOlution): The Russian word "эволюиия", which means evolution, is used in genitive case, however, it is written with two different alphabets, Cyrillic and Latin. The part that is written with Latin letters is fully capitalized and -vo letters are added after - Vol- to complete the brand name and draw attention to the brand. The graphical language game that is used in the commercial is based on a lexicalized word, although it is not in dictionary.

Достаточно одной «Секунды»!: (Enough only one "Second"!): In the advertisement slogan, the Russian word "секунда" (second), which is feminine gender, is used in genitive case. It is written between quotation marks and its initial letter is capitalized to draw attention to the brand name. Meanwhile, the slogan also draws attention to the adhesive power of the product. It is seen that the language game in the commercial benefits from polysemous word.

Клинское - Живи приПИВА!ючи (Klinskoje - Live in clover (colloquial style)!): The Russian synonym for beer is written as пиво but the letter -о in the last syllable is pronounced as $[a]$, because the first letter is stressed. Capitalized part of the приПИВА!ючи and the exclamation mark in the middle show, that it is a beer commercial. Furthermore, pronunciation of $n, u, \varepsilon, o[a]$ letters match. Writing the word "припеваючu", which means "in clover/happily", as "пива" instead of "пева", shows that a graphical language game is used in the advertisement slogan.

Лада - Нам иностранного не надо (Lada - We do not need foreign one): The advertisement slogan intends to persuade the consumers to prefer Lada vehicles manufactured in Russia, not the import vehicles. The stress is in the first syllable of the Russian expression "не надо" (не- negation particle), which means "wе do not need". For this reason the letter "-o" in the second syllable of the word is distressed and pronounced as $[a]$. $A, d, a$ sounds match in both words in terms of pronunciation. The language game used in the commercial is based on phonetic methods.

Новая форма мягкости водка «Мягков» (New form of softness of vodka "Miagkov"): The word "мягкость", which is used in Russian to express the softness of drinks and the $m, j a, g, k$, o letters (the first five letters) of the brand name "Мягков", written between quotation marks and capitalized in the advertisement slogan, match. The commercial uses a phonetic language game, in order to increase memorability.

Snickers. Не тормози - сникерсни (Snickers. Don't brake - Snickers it): To emphasize that product gives energy the advertisement slogan involves a Russian imperative "не тормози", which means do not brake. The slogan uses an imperative "сникерсни", which does not exist in Russian, but means eat a Snickers / Snickers it. It is seen that the advertisement slogan is created through a morphological language game. 
ФАНТА - Новая ФАНТАстическая бутылка ${ }^{3}$ (Zirka, 2011) (Fanta - New FANTAstic bottle): The Russian adjective "фантастическал", which is feminine gender and means fantastic is used in the fizzy drink commercial. The brand of the drink is emphasized by capitalizing the letters. The commercial uses a graphical language game.

Хватит мечтать - пора обLADAть (Lada - Stop dreaming - it's time to possess): The brand of the vehicle is emphasized by writing the word "лада" with Latin letters (LADA) and capitalized in the Russian verb "обладать", which means to possess. The commercial involves a graphical language game.

Чистота - чисто Тайд/Tide (Cleaning - Clean Tide): In the commercial of Taŭd/Tide detergent, the Russian word чистота which means cleanness is used as two separate words, after the hyphen, firstly, with the word чисто, which means clean in Russian and, secondly, with the brand name maŭd / tide. Since the stress is in the first syllable of "Yисто" the "-o" letter in the last syllable is pronounced as [a]. The last syllable "-mo" [-ma] and the first two letters [ma-] of maйd not only invite a rthymic expression, but also indicate that the advertisement benefits from a phonetic language game.

\section{Conclusion}

Every commercial film is an individual text that complies with all primary parameters and definitions of classical text. A commercial clearly differs from language material around it; both from the other commercials and from the language material, in which the advertisement block is placed. The commercial which is an individual communication unit has textual attributions, such as theme assets, pragmatic configuration, focus determined by the editors, content, working in accordance with the specified text model, special language structure, composition, purpose, conformity, integrity and stylistic conformity (Kon'kov, 2006, pp. 116-117).

Advertisement text editors often use language games in their seek of various lingual impact statements of advertisement products on consumers. Language games have specific expressions and make the advertisement message clear and memorable, so that advertisement definitely contributes to the sales ratio of the target product or service (Anokhina, 2013, p. 294).

The commercials which use the brand names in their slogans are identified in the review of the commercials broadcasted in Turkish and Russian TV channels. Nineteen commercials which are broadcasted on Turkish television channels and whose slogans involve the product brand are involved in the scope of the research, furthermore stylistic language games, preferred in terms of using brand in the advertisement slogans, are researched. Consequently, the frequency and the type of language games used in nineteen commercials are identified: seven polysemy, six graphical, one word repetition, one metaphorical, one lexical, one phonetic and two advertisements use both syntactic, word repetition and polysemy.

As for the Russian television channels, fifteen commercials which use the product brand in their slogans are involved in the scope of the research. Stylistic language game methods which are preferred in terms of using the brand in the advertisement slogans are reviewed: six phonetic, five graphical, two polysemy, one morphological and one lexical language game.

The commercials, which use the brand name in the slogan and are broadcasted on Turkish televisions, most frequently benefit from the polysemous traits of the words and graphical structure modification. Phonetic

\footnotetext{
${ }^{3}$ See from

http://lingvodnu.com.ua/arxiv-nomeriv/lingvistika-lingvokulturologiya-2011/reklama-sredstva-sozdaniya-ekspressii-v-semantikeslogana/
} 
and graphical items are the most preferred language games in the slogans of the commercials broadcasted on Russian televisions. No morphological language game is identified in Turkish advertisement slogans, however, only one Russian commercial used a morphological language game. In the course of the research, it is identified that the least preferred language games in Turkish advertisement slogans are based on phonetic, lexical, metaphorical and word repetition methods. As for the Russian advertisement slogans, it is identified that only two commercials involve polysemous words, however, the least preferred language games are based on morphological and lexical methods. The language games in Turkish and Russian television advertisement slogans are mostly based on graphical methods, similarly, as a common point, both nations used the lexical method least. But, the fact that two Turkish advertisement slogans benefit from word repetition and syntactic language game methods, while word repetition and syntactic language game methods are not identified in any Russian advertisement slogan, shows the difference between Russian and Turkish television advertisement slogans.

As a result of the research and the analysis, the advertisement texts are recommended to be reviewed under the literary-art stylistics, which is a subtitle of functional stylistics.

\section{References}

Anokhina, T. J. (Ed.). (2013). Glava 6.5.Jazykovaja igra v reklame (Chapter 6.5. Language games in the advertisement). In Stilistika i kul'tura russkoj rechi (Stylistics and culture of Russian speech). Moskva: Forum.

Ateşoğlu, İ. (2003). Marka inşasında slogan (Slogan in brand building). Süleyman Demirel Ün.IIBF Dergisi, 8(1), $259-264$. Retrieved from http://sablon.sdu.edu.tr/fakulteler/iibf/dergi/files/2003-1-16.pdf

Aytaç, G. (2000). IV.Üslup bilgisi (Stylistics). In Genel edebiyat bilimi (General literary science). İstanbul: Say.

Çınar, B., \& Karahan, L. (2009). Reklam dilinde kullanılan edebi sanatlar. Turkish Studies-International Periodical for the Languages, Literature and History of Turkish or Turkic, 4(8), 891-916. Retrieved from http://www.turkishstudies.net/Makaleler/1965794142_52-çınarbekir1689(Düzeltme).pdf

İnce, I. (1993). Reklam diline dilbilimsel bir bakış (A linguistic approach to language of advertisement). H.Ü. Edebiyat Fakültesi Dergisi, 10(1), 231-245. Retrieved from http://www.edebiyatdergisi.hacettepe.edu.tr/index.php/EFD/article/view/804/570

Kozhina, M. N., Duskaeva, L. R., \& Salimovsky, V. A. (2014). Vopros o stilevom statuse reklamnık tekstov i ikh stilistike, Kharasteristika funkcional'nykh stilej russkogo jazyka (The issue about the status of style of advertising texts and their stylistics, characterization of functional styles of Russian language). In Stilistika russkogo jazyka (Stylistics of Russian language). Moskva: Flinta.

Kon'kov, V. I. (2006). Stilisticheskaja neuporjadochennost' v rechevoj praktike SMI (Stylistic disorder in speech practice of mass media). In Sovremennaja russkaja rech': Sostojanie i funkcionirovanie (Modern Russian speech: Status and function) (pp. 112-118). Vypusk II (Issue II). Sankt-Peterburg: Osipov.

Lytkina, O. I., Selezneva, L. V., \& Skorokhodova, E. J. (2013). Polifunkcional'naja sistema literaturnogo jazyka, Vvedenie v prakticheskuju stilistiku (Multifunctional system of literary language, intoduction to practical stylistics). In Prakticheskaja stilistika russkogo jazyka (Practical stylistics of Russian language) (pp. 32-37). Moskva:Flinta.

Mengü M. M. (2006). Reklam sloganları ve tüketici zihni (Advertisement slogans and consumer's mind). İ.Ü. Illetişim Fakültesi Hakemli Dergisi, 25, 109-121. Retrieved from

http://www.journals.istanbul.edu.tr/iuifd/article/view/1019012333/1019011569

Okan, Z. A. (1998). Dil ve cinsiyet: reklam dili çözümlemesi (Language and gender: Analysis of advertising language). Ç.Ü. $\begin{array}{llllll}\text { Sosyal Bilimler Enstitüsü } \quad \text { Dergisi, } & \text { 5(5), } & \text { 187-198. } & \text { Retrieved from }\end{array}$ http://dergipark.ulakbim.gov.tr/cusosbil/article/view/5000000874/5000001565

Özünlü, Ü. (2001). Edebiyatta dil kullanımları (The use of language in literature). İstanbul: Multilingual.

Polonsky, A. V. (2009). Jazyk sovremennykh SMI: Kul'tura publichnogo dialoga (The language of modern mass media: Culture of public dialogue). Mir russkogo slova, 1, 62-66. Tema nomera: Jazyk i kompjuter (Theme of number: Language and computer). 
Serdobinceva, E. N. (2010). Struktura i jazyk reklamnikh tekstov: uchebnoe posobie (The structure and language of advertising texts: Training book). Moskva: Nauka.

Y1lmaz, E. (2004). Medyatik dil alanları:reklamcılık dili üzerine metin dil bilimsel bir inceleme (Mediatic language fields: A linguistic review of the text on advertising language). Türk Dili, (600). Retrieved from http://turkoloji.cu.edu.tr/DILBILIM/engin_yilmaz_reklamcilik_dili_metindilbilimsel_inceleme.pdf

Zirka, V. V. (2011). Reklama: sredstva sozdaniya ekspressii v semantike slogana (Advertisement: Means of creating expression in the semantics of a slogan). Retrieved from

http://lingvodnu.com.ua/arxiv-nomeriv/lingvistika-lingvokulturologiya-2011/reklama-sredstva-sozdaniya-ekspressii-v-sema ntike-slogana/

Bilim ve Sanat Terimleri Sözlüğü / İktisat Terimleri Sözlüğü (Dictionary of scientific and artificial terms/Dictionary of financial terms). Retrieved from

http://www.tdk.gov.tr/index.php?option=com_bts\&arama=kelime\&guid=TDK.GTS.5620db6ea8c1c1.36832821

Güncel Türkçe Sözlük (Contemporary Turkish dictionary). Retrieved from

http://www.tdk.gov.tr/index.php?option=com_gts\&arama=gts\&guid=TDK.GTS.57dfe5eab99c88.42242133 